Article

\title{
Anti-Thrombotic, Anti-Oxidant and Haemolysis Activities of Six Edible Insect Species
}

\author{
Su-Jin Pyo ${ }^{1}$, Deok-Gyeong Kang ${ }^{1}$, Chuleui Jung ${ }^{2}{ }^{\mathbb{D}}$ and Ho-Yong Sohn ${ }^{1, *}$ \\ 1 Department of Food and Nutrition, Andong National University, Andong 36729, Korea; \\ vytn0608@naver.com (S.-J.P.); kangdk107@naver.com (D.-G.K.) \\ 2 Department of Plant Medicals, Andong National University, Andong 36729, Korea; cjung@andong.ac.kr \\ * Correspondence: hysohn@anu.ac.kr; Tel.: +82-54-820-5491
}

Received: 28 February 2020; Accepted: 17 March 2020; Published: 1 April 2020

\begin{abstract}
In Korea, various insect species such as crickets and grasshoppers, as well as honey bee and silkworm pupae, have been consumed as food and used in oriental medicine. In this study to evaluate useful the bioactivities and potentially adverse effects of edible insects, ethanol extracts of Allomyrina dichotoma (AD), Tenebrio molitor (TM), Protaetia brevitarsis (PB), Gryllus bimaculatus (GB), Teleogryllus emma (TE), and Apis mellifera (AM) were prepared and evaluated with regard to their anti-thrombosis, anti-oxidant and haemolysis activities against human red blood cells. AD and TE extracts showed strong anti-oxidant activities, which were not related to polyphenol content. All ethanol extracts, except AM extract, showed strong platelet aggregation activities. The platelet aggregation ratios of the extracts were $194 \%-246 \%$ of those of the solvent controls. The effects of the $\mathrm{AD}, \mathrm{TM}, \mathrm{PB}, \mathrm{GM}$, and $\mathrm{AM}$ extracts on thrombin, prothrombin and various coagulation factors were negligible. Only the extract of TM showed concentration-dependent anti-coagulation activities, with a 1.75-fold aPTT (activated Partial Thromboplastin Time) extension at $5 \mathrm{mg} / \mathrm{mL}$. Of the six insect extracts, TM and AM extracts exhibited potent haemolytic activity. Our results on the insect extracts' functional properties suggest that edible insects have considerable potential not just as a food source but as a novel bio-resource as well.
\end{abstract}

Keywords: edible insect; blood coagulation; platelet aggregation; haemolysis; Teleogryllus emma

\section{Introduction}

As the imbalance between food production and consumption increases, the environmental burden to produce sufficient food creates diverse socio-economic concerns, compounded by climate change. To identify alternative food sources has thus become an important issue [1,2]. Insects are receiving particular attention as a sustainable alternative to meet future food demands and satisfy nutritional requirements [3-7]. It was estimated that at least 2000 species have been considered as edible by perhaps 2 billion people of various ethnic groups, representing approximately $30 \%$ of the global population [5].

In Korea, the use of insects in the traditional Korean medicine is an age-old practice $[8,9]$ and certain species like silkworms (Bombyx mori) and grasshoppers (Oxyoa sinuosa) have been accepted as regular food items throughout the country [9-12]. Several studies have demonstrated the potential and commercial value of insects in terms of their protein content, composition of essential amino acids, fatty acids and mineral content $[12,13]$. The results came from analyses of three species of beetles (Allomyrina dichotoma: Dynastidae; Protaetia brevitarsis: Cetoniidae; Tenebrio molitor: Tenebrionidae), two species of crickets (Teleogryllus emma and Gryllus bimaculatus: Gryllidae) and the honey bee Apis mellifera ligustica $[13,14]$. Recently, the useful bioactivities of certain insects, such as the anti-adipogenic effect of T. molitor larvae in 3T3-L1 adipocytes and anti-obesity effects of T. molitor larvae in high-fat 
diet-induced obese mice [15], as well as the cytotoxic effect of T. molitor larvae extract against prostate (PC3 and 22Rv1), cervix (HeLa), liver (PLC/PRF5, HepG2, Hep3B, and SK-HEP-1), colon (HCT116), lung (NCI-H460), breast (MDA-MB231), and ovary (SKOV3) cancer cells [16], and lipid and homocysteine-lowering effects of T. molitor larvae in the plasma and liver of obese Zucker rats [17], were reported. In addition, the anti-microbial peptides from A. mellifera (royalisin), Sacophaga peregrine (sapecin), Anopheles gambiae and B. mori (defensin A, B, C) [18], the haemolysis activity of crude venom and mellitin from $A$. mellifera and wasp $[19,20]$ and anti-exercise-fatigue activity of drone pupae extract of wasp in mice [21] were reported. However, limited information is available on their role as anti-oxidants and their bio-medical functional impact in connection with thrombosis-related issues and haemolysis remains unknown.

In this study, the effects of the extracts of six edible insect species on blood coagulation, platelet-aggregation, and anti-oxidant activities were investigated to develop functional food ingredients using edible insects. Since adverse effects of insect extracts, such as anemia due to haemolysis, are well reported [19,20], haemolysis involving red blood cells of the insect extracts was also investigated. Our results regarding the insect extracts' functional properties suggest that edible insects have considerable potential not just as a food source, but as a novel bio-resource as well.

\section{Materials and Methods}

\subsection{Materials}

Samples of Allomyrina dichotoma (AD), Tenebrio molitor (TM), Protaetia brevitarsis (PB), Gryllus bimaculatus (GB), and Teleogryllus emma (TE) were obtained from commercial insect farms in Korea during May 2016, and sample of Apis mellifera (AM) was collected by A.B. Jessen, University of Copenhagen, Demark during the late summer in 2016 (Table 1). Details of the farming methods and culturing environments for the six edible insect species have previously been reported [13,14]. Insect samples were previously washed off by room-temperature water and dried. Not all insects were starved, except $\mathrm{AD}$ and $\mathrm{PB}$, which were starved at the last instar for days to clean out the digestive tracks. The wings of honey bee drone adults were removed. All the samples were freeze-dried for at least $72 \mathrm{~h}$ at or below $-50{ }^{\circ} \mathrm{C}$, since killing insects with chemical or other physical means would have an influence on their bio-functionality. The dried samples were ground into powder and stored at $-20^{\circ} \mathrm{C}$ until further analyses. Reagent-grade chemicals were purchased from Fisher Scientific (Hampton, NH, USA). The blood samples were provided from Daegu-Gyeungbook Blood Center in Korea as Research blood. The study was conducted in accordance with the Declaration of Helsinki, and the protocol was approved by the Ethics Committee of Andong National University in Korea (IRB-Andong National Univ-482: 1040191-201602-BR-001-01, and IRB-Andong National Univ-1312: 1040191-202002-BR-001-01). Blood tests were conducted as a received state on the received day (same-day experiments), as recommended by suppliers.

Table 1. List of preferred insects used as food, feed, and oriental medicine in Korea.

\begin{tabular}{ccccc}
\hline Sample & Scientific Name & Classification & Feed & Life Stage \\
\hline AD & Allomyrina dichotoma & Coleoptera Dynastidae & Fermented sawdust & Larvae \\
\hline TM & Tenebrio molitor & Coleoptera Tenebrionidae & Rice, bran & Larvae \\
\hline PB & Protaetia brevitarsis & Coleoptera Cetoniidae & Rice, bran, Organic soil & Larvae \\
\hline GB & Gryllus bimaculatus & Orthoptera Gryllidae & Rice, bran, Vegetables & Late nymph \\
\hline TE & Teleogryllus emma & Orthoptera Gryllidae & Rice, bran, Vegetables & Late nymph \\
\hline AM & Apis mellifera & Hymenoptera Apidae & Honey, pollen & Adult \\
\hline
\end{tabular}




\subsection{Sample Preparation}

To prepare ethanol extracts, $5 \mathrm{~g}$ of the lyophilized powders of the six edible insect species were dissolved with $100 \mathrm{~mL}$ of ethanol (95\%, Daejung Chemicals \& Metals Co., Ltd. Siheung, Korea) and extracted three times at room temperature. After that, the extract was filtered by paper (Whatsman No. 2) and concentrated under reduced pressure (Eyela Rotary evaporator, N-1000, Tokyo Rikakikai Co., Ltd., Tokyo, Japan). The powders of insects extracts were prepared using freeze dryer equipment (FD5508, Ilshin Lab Co. Ltd., Korea), and the insect samples were dissolved in dimethylsulfoxide (DMSO) at suitable concentrations for functional component analyses.

\subsection{In-vitro Anti-Coagulation Activity}

The insect extracts were dissolved in DMSO, and anti-coagulation activity was measured by determining the clotting times required for the activation of thrombin (TT: Thrombin Time), prothrombin (PT: Prothrombin Time) and coagulation factors (aPTT: activated Partial Thromboplastin Time). TT, PT and aPTT were determined following the supplier's instructions (Ameulung coagulometer, Lemgo, Germany) [22]. For the TT assay, $50 \mu \mathrm{L}$ thrombin (0.5U, Sigma Co., St Louis, MO, USA), $50 \mu \mathrm{L} \mathrm{CaCl}_{2}$ $(50 \mathrm{mM})$ and $10 \mu \mathrm{L}$ insect extract were added to a preheated $\left(37^{\circ} \mathrm{C}\right)$ test tube and incubated at $37^{\circ} \mathrm{C}$ for $3 \mathrm{~min}$. Then, $100 \mu \mathrm{L}$ preheated $\left(37^{\circ} \mathrm{C}\right.$ ) control plasma (MD Pacific Technology Co., Ltd., Huayuan Industrial Area, Tianjin, China) was added; the time (in seconds) from the addition of the control plasma to the detection of clot formation was measured and defined as the TT. For the PT assay, $70 \mu \mathrm{L}$ control plasma and $10 \mu \mathrm{L}$ insect extract were added to a preheated $\left(37^{\circ} \mathrm{C}\right)$ test tube and incubated at $37^{\circ} \mathrm{C}$ for $3 \mathrm{~min}$. Then, $130 \mu \mathrm{L}$ preheated $\left(37^{\circ} \mathrm{C}\right) \mathrm{PT}$ reagent (MD Pacific Technology Co., Ltd., Huayuan Industrial Area, Tianjin, China) was added; the time (in seconds) from the addition of PT reagent to the detection of clot formation was measured and defined as the PT. For the aPTT assay $70 \mu \mathrm{L}$ control plasma and $10 \mu \mathrm{L}$ insect extract were mixed in a preheated test tube at $37^{\circ} \mathrm{C}$ for $3 \mathrm{~min}$, and $65 \mu \mathrm{L}$ preheated $\left(37^{\circ} \mathrm{C}\right)$ aPTT reagent (MD Pacific Technology Co., Ltd., Huayuan Industrial Area, Tianjin, China) was added and incubated at $37^{\circ} \mathrm{C}$ for $3 \mathrm{~min}$. Then, $65 \mu \mathrm{L} \mathrm{CaCl}_{2}(35 \mathrm{mM})$ preheated to $37^{\circ} \mathrm{C}$ was added. The time (in seconds) from the addition of $\mathrm{CaCl}_{2}$ to the detection of clot formation was measured and defined as the aPTT [22]. Aspirin $(1.5 \mathrm{mg} / \mathrm{mL}$ of acetylsalicylic acid, Sigma, St. Louis, MO, USA), which inhibits thrombin generation and clot formation at high doses (300-500 $\mathrm{mg} /$ day) [23], was used as positive control. All data are presented as the mean \pm SD values of triplicates.

\subsection{In Vitro Platelet Aggregation Activity}

The effects of the insect extracts on platelet aggregation were measured using Whole Blood Aggregometer (Chrono-log, Havertown, PA, USA) [24]. The PRP obtained from human blood was washed with washing buffer, and the washed platelets $\left(5 \times 10^{8}\right.$ cells/mL) were suspended using buffer containing $138 \mathrm{mM} \mathrm{NaCl}, 2.7 \mathrm{mM} \mathrm{KCl}, 12 \mathrm{mM} \mathrm{NaHCO}_{3}, 0.36 \mathrm{mM} \mathrm{NaH}_{2} \mathrm{PO}_{4}, 5.5 \mathrm{mM}$ glucose, $0.49 \mathrm{mM} \mathrm{MgCl} 2$, and $0.25 \%$ gelatin ( $\mathrm{pH} 7.4$ ). The platelets were then incubated with the insect extracts, followed by stimulation with $2.5 \mu \mathrm{L}$ of collagen $(1 \mathrm{mg} / \mathrm{mL})$ at $37^{\circ} \mathrm{C}$ for $12 \mathrm{~min}$. Impedance changes were monitored and amplitude, slope and area under the curve (AUC) were calculated using Aggrolink program (Aggrolink 5.2.3, Chrono-log, Havertown, PA, USA). Amplitude was expressed as ohms by the maximum extent of platelet aggregation and slope (rate of reaction) was determined by drawing a tangent through the steepest part of the curve. AUC was calculated from the platelet aggregation curve [22]. Platelet aggregation was calculated according to the following equation: (AUC of samples/AUC of DMSO) $\times 100$ [24]. Aspirin, which inhibits the COX- 1 and reduce thromboxane A2 synthesis at low concentration (100 mg/day) [25], was used as positive control of anti-platelet aggregation. 


\subsection{Haemolysis Activity}

A human blood sample was diluted in phosphate-buffered saline (PBS; pH 7.4) and centrifuged at $200 \times g$ for $10 \mathrm{~min}$. After three washes, the final concentration of the erythrocytes was adjusted to $4 \%$. The erythrocyte suspension was transferred into 96-well plates and incubated with the insect extract at $37^{\circ} \mathrm{C}$ for $1 \mathrm{~h}$. The plate was centrifuged at $200 \times g$ for $10 \mathrm{~min}$. The supernatant was collected and aliquoted and haemolysis was evaluated by determining the release of haemoglobin from the $4 \%$ human erythrocyte suspension at $414 \mathrm{~nm}$ with an ELISA reader. Zero percent and 100\% haemolysis activities were evaluated with PBS alone and $0.1 \%$ Triton X-100, respectively. Haemolysis percentage was calculated using the following equation: haemolysis $(\%)=\left(\left(A_{414 \mathrm{~nm}}\right.\right.$ in the bee samples $-A_{414 \mathrm{~nm}}$ in PBS $) /\left(A_{414} \mathrm{~nm}\right.$ in $0.1 \%$ Triton X-100 $-A_{414 \mathrm{~nm}}$ in PBS $\left.)\right) \times 100$ [26].

\subsection{In-Vitro Anti-oxidant Activity}

DPPH (1,1-diphenyl-2-picryl hydrazyl) anion scavenging ability, ABTS (2,2-azobis(3ethylbenzothiazoline-6-sulfonate)) cation scavenging activity, nitrite scavenging activity and reducing power were evaluated following previously reported methods $[27,28]$. Ascorbic acid (Sigma Co., St. Louis, MO, USA) was used as positive control. Each activity rating was expressed as the mean and the deviation of each of three replicates.

DPPH radical scavenging activity of insect extracts was assessed according to the method described by Suzuki et al. [27]. The ability of insect extracts to scavenge DPPH free radicals was evaluated with reference to the results obtained for the ascorbic acid standard curve $\left(0-1 \mathrm{mg} 100 \mathrm{~mL}^{-1}\right)$. The absorbance at $516 \mathrm{~nm}$ was measure using an Ultraviolet-visible spectrophotometer (Epouch Microplate reader, Biotek Instrument Inc., Winooski, VT, USA).

ABTS $\bullet^{+}$radical scavenging activity was measured using the ABTS radical cation decolorization assay, as described by Suzuki et al. [27]. The ability of insect extracts to scavenge ABTS ${ }^{+}$radicals was evaluated with reference to the results obtained for the ascorbic acid (Sigma Co., St. Louis, MO, USA) standard curve (0-1 mg $\left.100 \mathrm{~mL}^{-1}\right)$. The absorbance at $734 \mathrm{~nm}$ was measured using a UV-visible spectrophotometer (Epouch Microplate reader, Biotek Instrument Inc., Winooski, VT, USA).

The nitrite scavenging activity of the insect extracts was assessed according to the method described by Kim et al. [29] with some modification. A total of $5.0 \mathrm{~mL}$ insect extracts were mixed with sodium nitrite $(1 \mathrm{~mL}, 0.01 \%)$ and citrate-phosphate buffer $(\mathrm{pH} 1.2)$ and adjusted to a volume of $10 \mathrm{~mL}$ with distilled water. The reaction solution was incubated at $37^{\circ} \mathrm{C}$ for $1 \mathrm{~h}$. Then, $3 \mathrm{~mL}$ of the reaction solution were mixed with $3 \mathrm{~mL}$ Griess reagent. After vigorous mixing with a vortex, the mixture was placed at room temperature for $15 \mathrm{~min}$ and the absorbance at $520 \mathrm{~nm}$ was recorded as A; B was the absorbance of the control group (water instead of sample solutions); $C$ was the absorbance of the insect extract. Nitrite scavenging activity was calculated by the following equation: $(1-(\mathrm{A}-\mathrm{C}) / \mathrm{B}) \times 100$ [27].

The reducing power of the insect extracts was assayed according to the method used by Jayaprakasha et al. [30] with some modifications. Briefly, $2.5 \mathrm{~mL}$ of insect extracts in ethanol were mixed with $2.5 \mathrm{~mL}$ of phosphate buffer $(0.2 \mathrm{~mol} / \mathrm{L}, \mathrm{pH} 6.6)$ and $2.5 \mathrm{~mL}$ of potassium ferricyanide $(10 \%)$. The mixtures were incubated for $20 \mathrm{~min}$ at $50{ }^{\circ} \mathrm{C}$. Then, $2.5 \mathrm{~mL}$ of trichloroacetic acid $(10 \%)$ and $0.5 \mathrm{~mL} \mathrm{FeCl}_{3}(0.1 \%)$ were added to the mixture and incubated for $10 \mathrm{~min}$; absorbance was measured at $700 \mathrm{~nm}$ against the buffer. Ascorbic acid was used as the standard.

\subsection{Component Analysis}

The total polyphenol content of the six insect extracts was measured colorimetrically by using Folin-Ciocalteu's phenol reagent [31]. Distilled water of $2.6 \mathrm{~mL}$ and $200 \mu \mathrm{L}$ of Folin-Ciocalteu's phenol reagent were added to $200 \mu \mathrm{L}$ of the sample and mixed together; the mixture was allowed to react for $6 \mathrm{~min}$ at room temperature and then $2 \mathrm{~mL}$ of $7 \%(\mathrm{w} / \mathrm{v}) \mathrm{Na}_{2} \mathrm{CO}_{3}$ solution was added. The mixture was then allowed to react for $30 \mathrm{~min}$ at $30^{\circ} \mathrm{C}$, and the absorbance was measured using a spectrophotometer 
(Epouch Microplate reader, Biotek Instrument Inc., Winooski, VT, USA) at $700 \mathrm{~nm}$. A standard curve was constructed using rutin as the standard.

The total flavonoid content in the six insect extracts was measured by the aluminium colorimetic method [32]. Distilled water of $320 \mu \mathrm{L}$ and $15 \mu \mathrm{L}$ of $5 \%$ (w/v) $\mathrm{NaNO}_{2}$ added to $100 \mu \mathrm{L}$ of the sample were mixed together and allowed to react for $5 \mathrm{~min}$. Then, $10 \% \mathrm{AlCl}_{3}$ solution was added and the mixture was reacted for $1 \mathrm{~min}$ before $1 \mathrm{M} \mathrm{NaOH}$ was added; subsequently, the absorbance was measured at $510 \mathrm{~nm}$. A standard curve was constructed using tannic acid as a standard substance. Total sugar content was measured by the phenol-sulfuric acid method in microplate format [33], and the reducing sugar content was measured by the DNS method [34]. A standard curve was constructed using sucrose and glucose, respectively.

\subsection{Statistical Analysis}

Each activity value was expressed as the mean and the standard deviation of each of three replicates. Data were analyzed using SPSS packages (version 25). One-way analysis of variance (ANOVA) and Duncan Multiple Range Test at the level $(p<0.05)$ were used for the overall analysis of variance and mean separation, respectively.

\section{Results}

\subsection{Component Anlysis of Ethanol Extracts}

The ethanol extracts for AD, TM. PB, GB, TE and AM were prepared and their extraction yields are shown in Table 2. The highest yield was observed in TM (40.5\%) and followed by TE, PB, AD, GB and AM yields. The ethanol extraction yields were closely related to the content of crude lipid and oil of the insect samples $[13,14]$. Total polyphenol content showed that the GB and TE extracts possess $15.5-15.6 \mathrm{mg} / \mathrm{g}$, whereas the AD extract has only $1.3 \mathrm{mg} / \mathrm{g}$. Analysis of total flavonoid content showed that the AD extract possesses $5.7 \mathrm{mg} / \mathrm{g}$, whereas the TM extract contains only $0.1 \mathrm{mg} / \mathrm{g}$. Total sugar $(89.3 \pm 0.8 \mathrm{mg} / \mathrm{g})$ and reducing sugar content $(56.7 \pm 1.5 \mathrm{mg} / \mathrm{g})$ of the extract of AM were found to be the highest of the six insect extracts.

Table 2. Yields and component assay of the ethanol extracts of 6 different insect species.

\begin{tabular}{cccccc}
\hline \multirow{2}{*}{ Extract } & \multirow{2}{*}{ Yields (\%) } & \multicolumn{4}{c}{ Component (mg/g) } \\
\cline { 3 - 6 } & & Total Polyphenol & Total Flavonoid & Total Sugar & Reducing Sugar \\
\hline AD & 23.1 & $1.3 \pm 0.1^{\mathrm{a}}$ & $5.7 \pm 0.1^{\mathrm{d}}$ & $13.0 \pm 0.1^{\mathrm{b}}$ & $1.8 \pm 0.0^{\mathrm{a}}$ \\
\hline TM & 40.5 & $2.6 \pm 0.2^{\mathrm{b}}$ & $0.1 \pm 0.1^{\mathrm{a}}$ & $28.7 \pm 1.0^{\mathrm{c}}$ & $8.5 \pm 0.2^{\mathrm{c}}$ \\
\hline PB & 24.9 & $11.8 \pm 0.3^{\mathrm{c}}$ & $3.5 \pm 0.3^{\mathrm{b}}$ & $31.5 \pm 0.4^{\mathrm{d}}$ & $13.0 \pm 0.3^{\mathrm{d}}$ \\
\hline GB & 19.7 & $15.6 \pm 0.3^{\mathrm{d}}$ & $3.9 \pm 0.3^{\mathrm{b}}$ & $7.9 \pm 0.3^{\mathrm{a}}$ & $7.5 \pm 0.3^{\mathrm{c}}$ \\
\hline TE & 30.1 & $15.5 \pm 0.9^{\mathrm{d}}$ & $4.7 \pm 0.2^{\mathrm{c}}$ & $8.5 \pm 0.2^{\mathrm{a}}$ & $6.1 \pm 0.4^{\mathrm{b}}$ \\
\hline AM & 14.2 & $12.4 \pm 0.2^{\mathrm{c}}$ & $4.5 \pm 0.3^{\mathrm{c}}$ & $89.3 \pm 0.8^{\mathrm{e}}$ & $56.7 \pm 1.5^{\mathrm{e}}$ \\
\hline \multicolumn{2}{r}{ Different superscripts within a column indicate statistically significant differences $(p<0.05)}$.
\end{tabular}

\subsection{In Vitro Anti-Coagulation Activity}

The anti-coagulation activities of the ethanol extracts of the six insect species were determined by measuring their TT, PT and aPTT. Treatment of aspirin $(1.5 \mathrm{mg} / \mathrm{mL})$ as positive control extended the clotting time to 1.64-fold of TT, 1.39-folds of PT, and 1.37-folds of aPTT compared with non-treatment (DMSO as solvent control) (Table 3$)$. The treatment of high concentrations of aspirin $(5 \mathrm{mg} / \mathrm{mL})$ extended the clotting time to above 15-fold of TT, PT and aPTT compared with non-treatment. Treatment of the insect extracts $(5.0 \mathrm{mg} / \mathrm{mL})$ of AD, TM. PB, GB, and AM did not show significant changes in the clotting times of TT, PT and aPTT. However, the TE extract $(5.0 \mathrm{mg} / \mathrm{mL})$ was found to significantly 
extend TT (1.31-fold) and aPTT (1.75-fold) (Table 3), and the anti-coagulation effects of TE extract could be shown to be concentration-dependent (Figure 1).

Table 3. Effect of the ethanol extracts of 6 different insect species on blood coagulation.

\begin{tabular}{ccccc}
\hline \multirow{2}{*}{ Extract/Chemicals } & $\begin{array}{c}\text { Concentration } \\
(\mathbf{m g} / \mathbf{m L})\end{array}$ & \multicolumn{2}{c}{ Anti-Coagulation Activity (Multiplication of Control) } \\
\cline { 2 - 4 } & - & TT $^{\mathbf{1}}$ & PT $^{\mathbf{2}}$ & aPTT $^{\mathbf{3}}$ \\
\hline DMSO & 1.5 & $1.00 \pm 0.07^{\mathrm{bc}}$ & $1.00 \pm 0.00^{\mathrm{a}}$ & $1.00 \pm 0.01^{\mathrm{b}}$ \\
\hline \multirow{2}{*}{ Aspirin } & 5.0 & $>15.0$ & $1.39 \pm 0.02^{\mathrm{e}}$ & $1.37^{\mathrm{a}} \pm 0.03^{\mathrm{d}}$ \\
\cline { 2 - 4 } & 5.0 & $1.10 \pm 0.01^{\mathrm{d}}$ & $1.02 \pm 0.02^{\mathrm{ab}}$ & $1.11^{\mathrm{f}} \pm 0.10^{\mathrm{c}}$ \\
\hline AD & 5.0 & $0.90 \pm 0.00^{\mathrm{a}}$ & $1.13 \pm 0.03^{\mathrm{c}}$ & $0.93 \pm 0.01^{\mathrm{ab}}$ \\
\hline TM & 5.0 & $1.04 \pm 0.03^{\mathrm{c}}$ & $1.20 \pm 0.01^{\mathrm{d}}$ & $0.95 \pm 0.01^{\mathrm{ab}}$ \\
\hline PB & 5.0 & $0.96 \pm 0.00^{\mathrm{b}}$ & $1.18 \pm 0.00^{\mathrm{d}}$ & $0.90 \pm 0.02^{\mathrm{a}}$ \\
\hline GB & 5.0 & $1.31 \pm 0.01^{\mathrm{e}}$ & $1.05 \pm 0.02^{\mathrm{b}}$ & $1.75 \pm 0.02^{\mathrm{e}}$ \\
\hline TE & 5.0 & $1.04 \pm 0.04^{\mathrm{c}}$ & $1.03 \pm 0.04^{\mathrm{ab}}$ & $0.96 \pm 0.00^{\mathrm{ab}}$ \\
\hline AM & 5.0 &
\end{tabular}

Anti-coagulation activity was calculated on the clotting time of a given sample divided by the clotting time of the solvent control in blood coagulation assays. The thrombin $\left(\mathrm{TT}^{1}\right)$, prothrombin $\left(\mathrm{PT}^{2}\right)$ and activated partial thromboplastin times $\left(\mathrm{aPTT}^{3}\right.$ ) of the solvent control (DMSO) were $31.5 \mathrm{~s}, 20.5 \mathrm{~s}$ and $80.9 \mathrm{~s}$, respectively. Data are means \pm SD of triplicate determinations. Different superscripts within a column indicate statistically significant differences $(p<0.05)$.
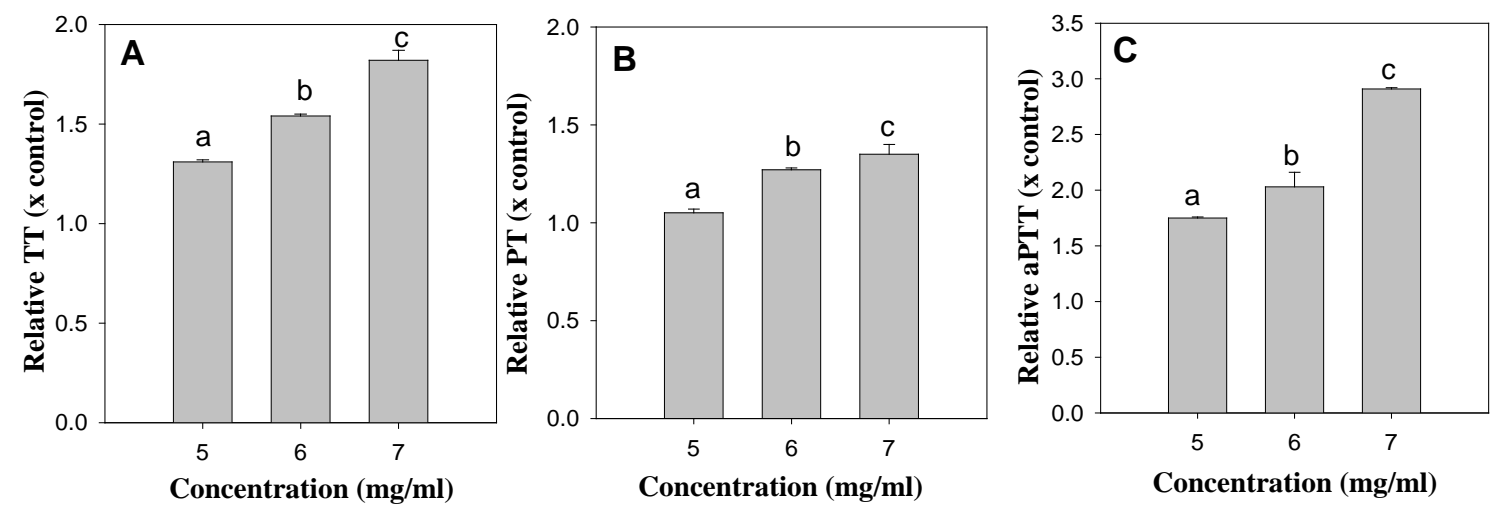

Figure 1. The concentration-dependent anti-coagulation activities of TE extract. (A): TT changes by TE extract, (B): PT changes by TE extract, $(\mathbf{C})$ : aPTT changes by TE extract. Different superscripts within a panel indicate statistically significant differences $(p<0.05)$.

\subsection{In-vitro Platelet Aggregation Activities}

Since the platelet aggregation is strongly inhibited by aspirin [25], the changes in PAR (platelet aggregation ratio) by aspirin treatments were determined. At 0.25 and $0.125 \mathrm{mg} / \mathrm{mL}$ of aspirin, the PARs were $38.9 \%$ and $54.3 \%$ compared with non-treatment (Table 4, Figure 2). Strong and rapid activations of platelet aggregation were identified by treatment of the insect extract $(0.25 \mathrm{mg} / \mathrm{mL})$ of AD, TM, PB, GB and TE. The PARs of these insect extracts were $194.5 \%-246.1 \%$ compared with nontreatment. Only AM treatment $(0.25 \mathrm{mg} / \mathrm{mL})$ did not alter the platelet aggregation 
Table 4. Effect of the ethanol extracts of 6 different insect species on platelet aggregation.

\begin{tabular}{ccccccc}
\hline Extract/Chemicals & $\begin{array}{c}\text { Concentration } \\
(\mathbf{m g} / \mathbf{m L})\end{array}$ & $\begin{array}{c}\text { Amplitude } \\
(\mathbf{o h m})\end{array}$ & Slope & $\begin{array}{c}\text { Lag Time } \\
\mathbf{( s )}\end{array}$ & $\begin{array}{c}\text { Area Under } \\
\text { Curve }\end{array}$ & PAR $^{\mathbf{1}}$ (\%) \\
\hline \multirow{2}{*}{ DMSO } & - & 20 & 3 & 51 & 130.6 & 102.7 \\
\cline { 2 - 7 } & - & 20 & 3 & 59 & 123.7 & 97.3 \\
\hline \multirow{2}{*}{ Aspirin } & 0.25 & 9 & 1 & 60 & 49.4 & 38.9 \\
\hline AD & 0.125 & 13 & 2 & 67 & 69.1 & 54.3 \\
\hline TM & 0.25 & 27 & 4 & 17 & 215.3 & 194.5 \\
\hline PB & 0.25 & 27 & 6 & 13 & 249.1 & 195.9 \\
\hline GB & 0.25 & 26 & 8 & 8 & 262.5 & 206.4 \\
\hline TE & 0.25 & 28 & 6 & 8 & 248.9 & 195.8 \\
\hline AM & 0.25 & 25 & 12 & 1 & 272.4 & 246.1 \\
\hline
\end{tabular}

${ }^{1}$ PAR: Platelet Aggregation Ratio. Data are presented as representative results relative to three independent determinations. Amplitude is expressed as ohms by maximum extent of platelet aggregation, and slope (rate of reaction) is determined by drawing a tangent through the steepest part of curve. Area under the curve (AUC) was calculated from the platelet aggregation curve.

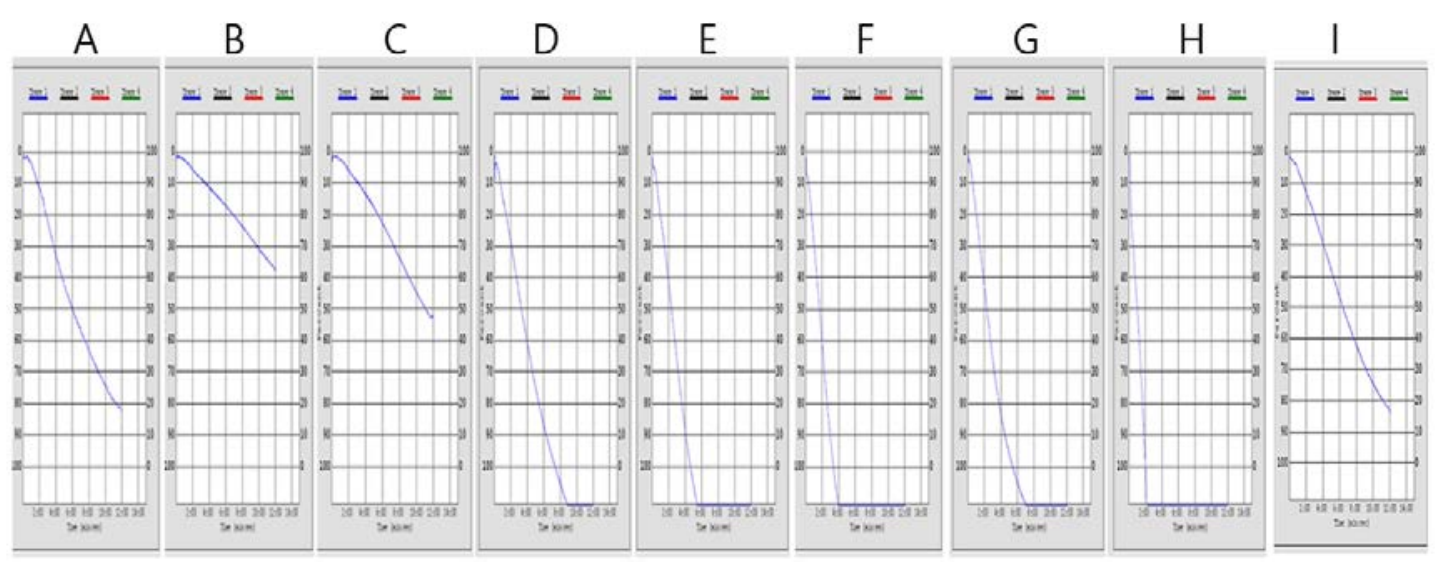

Figure 2. Impedance changes during platelet aggregation after addition of aspirin and the insect extracts in whole blood aggregometer. (A) DMSO, (B) aspirin $(0.25 \mathrm{mg} / \mathrm{mL}),(\mathbf{C})$ aspirin $(0.125 \mathrm{mg} / \mathrm{mL}),(\mathbf{D}) \mathrm{AD}$ extract $(0.25 \mathrm{mg} / \mathrm{mL})$, (E) TM extract $(0.25 \mathrm{mg} / \mathrm{mL}),(\mathbf{F})$ PB $(0.25 \mathrm{mg} / \mathrm{mL}),(\mathbf{G})$ GB extract $(0.25 \mathrm{mg} / \mathrm{mL})$, (H) TE extract $(0.25 \mathrm{mg} / \mathrm{mL})$ and (I) AM extract $(0.25 \mathrm{mg} / \mathrm{mL})$, respectively.

\subsection{Haemolytic Activities}

Haemolytic activities of the insect extracts were evaluated. Treatment with amphotericin B, known to possess potent haemolytic activity [26], and used as antifungal and anticancer agent, resulted in $53.4 \%$ haemolysis at $0.0125 \mathrm{mg} / \mathrm{mL}$ and $89.0 \%$ haemolysis at $0.025 \mathrm{mg} / \mathrm{mL}$ (Table 5). Among the insect extracts, AD, TM, PB and GB did not produce haemolysis up to $1.0 \mathrm{mg} / \mathrm{mL}(0.0-7.6 \%$ of haemolysis). However, the TE and AM extracts revealed potent haemolytic activity $(94.5-97.5 \%)$ at $1.0 \mathrm{mg} / \mathrm{mL}$. The calculated $\mathrm{HC}_{50} \mathrm{~s}$ (the concentration for $50 \%$ haemolysis) for amphotericin $\mathrm{B}$, TE and AM extracts were $0.015,0.236$ and $0.396 \mathrm{mg} / \mathrm{mL}$, respectively. 
Table 5. Haemolytic activities of the ethanol extracts of 6 different insect extracts.

\begin{tabular}{ccc}
\hline Extract/Chemicals & Concentration $(\mathbf{m g} / \mathbf{m L})$ & Haemolysis $(\%)$ \\
\hline DMSO & - & $0.0 \pm 1.4^{\mathrm{a}}$ \\
\hline Triton X-100 & 1.0 & $100.0 \pm 0.4^{\mathrm{e}}$ \\
\cline { 2 - 3 } & 0.05 & $99.1 \pm 0.4^{\mathrm{e}}$ \\
\cline { 2 - 3 } Amphotericin B & 0.025 & $89.0 \pm 0.6^{\mathrm{d}}$ \\
\cline { 2 - 3 } & 0.0125 & $53.4 \pm 0.2^{\mathrm{c}}$ \\
\cline { 2 - 3 } & 0.0063 & $1.1 \pm 0.8^{\mathrm{a}}$ \\
\hline AD & 0.0032 & $0.0 \pm 0.4^{\mathrm{a}}$ \\
\hline TM & 1.0 & $2.4 \pm 0.5^{\mathrm{a}}$ \\
\hline PB & 1.0 & $7.6 \pm 1.3^{\mathrm{b}}$ \\
\hline GB & 1.0 & $0.0 \pm 3.5^{\mathrm{a}}$ \\
\hline TE & 1.0 & $1.1 \pm 0.5^{\mathrm{a}}$ \\
\hline AM & 1.0 & $97.5 \pm 2.2^{\mathrm{e}}$ \\
\hline
\end{tabular}

Different superscripts within a column indicate statistically significant differences $(p<0.05)$.

\subsection{In-Vitro Anti-Oxdant Activities}

Oxidative stress is closely related to fibrin clot formation. Inappropriate posttranslational modification of fibrin and RBC haemolysis play roles in thrombotic disorders [35-37]. The assay of anti-oxidant activities showed that the AD and TE extracts $(0.5 \mathrm{mg} / \mathrm{mL})$ have potent DPPH anion scavenging power $(59.9 \%$ for $\mathrm{AD}$ extract and $68.3 \%$ for TE extract), and ABTS cation scavenging activities (64.3\% for AD extract and $62.1 \%$ for TE extract). The reducing powers of the AD, TE and AM extracts were found to be stronger than the extracts of TM, PB, GB and AM. Potent nitrite scavenging activity was observed in the PB and AM extracts.

\section{Discussion}

Insects and their solvent extractions have been used as medicinal resources and to promote health in Asian countries including China, Japan, and Korea and for a long time [38]. In Korea, the extract of PB has been used to treat inflammatory disease [39] and the extract of GB and Aspongopus chinensis has widely been used to treat inflammation $[40,41]$. Recent research demonstrated that various invertebrates have potent anti-thrombotic activities. The anti-thrombotic and fibrinolytic activities of Lumbricus rubellus [42] and anticoagulants from Holotrichia diomphalia larvae [43] are well reported. Furthermore, several anti-thrombotic compounds were identified, for example, the $\mathrm{N}$-acetyltyramine, hydroxytyrosol and several diketopiperazines, which have anti-FXa and anti-platelet activities as in the TM [44], anti-platelet alkaloids from Scolopendra subspinipes [45], anti-platelet simplagrin from Simulium nigrimanum salivary glands [46], anticoagulant peptides from the mosquito Culex pipiens [47] and horsefly salivary glands [48], as well as Bombyx batryticatus [49]. However, assessments of the anti-thrombosis activities along with haemolytic and anti-oxidant activities of various edible insects are scarce.

In this study, the high polyphenol contents (12.4-15.6 mg/g) and flavonoid contents (3.5-4.7 mg/g) were found in PB, GB, TE and AM extract (Table 2). However, the TM extract has $2.6 \mathrm{mg} / \mathrm{g}$ of polyphenol and $0.1 \mathrm{mg} / \mathrm{g}$ of flavonoid. The TM extract showed the lowest anti-oxidant activities among the insect extracts used. The contents of total sugar and reducing sugar in AM extract showed 3-10 folds higher than the other insect extracts. High level of sugars in AM would have been influenced by the feeding honey in the hive. However, the bee venom would not influence the results because we used only 
drones which lack the venom gland. Some insects also produce toxic substances such as benzoquinones from Tenebrio molitor under stress [50]. However, we tried to standardize the sampling and preparation process generic to all species we studied.

We have determined the effects of the ethanol extracts of six edible insects (AD, TM, PB, GB, $\mathrm{TE}$ and $\mathrm{AM}$ ) on blood coagulation and platelet aggregation. Extracts of these insect species have traditionally been considered as a part of anti-thrombotic oriental medicines in Korea. Only the TE extract showed significant and concentration-dependent inhibition against thrombin, prothrombin and blood coagulation factors (Table 3, Figure 1). However, the TE extract at $0.25 \mathrm{mg} / \mathrm{mL}$ showed the most potent platelet aggregation among the six insect extracts (Table 4, Figure 2). Considering the importance of platelet aggregation in thrombus formation as a primary haemostasis plug [24], the TE extract may result in accelerated thrombus formation.

The TE and AM extracts had strong haemolytic activities against red blood cells (Table 5). Red blood cells (RBC) are the most abundant cell type in the blood and play an essential role in oxygen transfer. Several natural plant extracts and compounds of plants and/fungi, such as saponins, phenylhydrazine, penicillin, and cephalosporin induce haemolysis and result in erythrokatalysis [51-54]. Haemolysis of the $\mathrm{RBC}$ results in an exposure of intracellular phosphatidylserine, which accelerates blood coagulation and hyper-coagulable states [55]. Therefore, strong haemolysis activities of the TE extract may also contribute to the formation of fibrin clots.

The extracts of AD and TE exhibit strong radical scavenging activities along with reducing powers (Table 6). Previous reports [35-37] have suggested that oxidative stress increases the modification of fibrin and RBC haemolysis. Thus, the strong anti-oxidant activities of these insect extracts may contribute to delayed blood clot formation, and ROS-induced cellular damage. However, our in vitro results on the coagulation and platelet aggregation assay did not suggest an anti-thrombotic effect of the insect extracts. Our results suggest that the ethanol extracts have haemostatic rather than anti-thrombotic activities. Further research on the purification of the thrombosis-related compounds and their underlying mechanism in vivo is required.

Table 6. Anti-oxidant activities of the ethanol extracts of 6 different insect species.

\begin{tabular}{ccccc}
\hline \multirow{2}{*}{ Extract } & \multicolumn{2}{c}{ Scavenging Activity [SA] (\%) } & \multirow{2}{*}{$\begin{array}{c}\text { Reducing Power } \\
\text { Abs. 700 }\end{array}$} \\
\cline { 2 - 4 } & DPPH SA & ABTS SA & Nitrite SA & $0.269 \pm 0.007^{\mathrm{d}}$ \\
\hline AD & $59.9 \pm 0.8^{\mathrm{e}}$ & $64.3 \pm 2.5^{\mathrm{d}}$ & $24.5 \pm 0.7^{\mathrm{ab}}$ & $0.034 \pm 0.008^{\mathrm{a}}$ \\
\hline $\mathrm{TM}$ & $4.8 \pm 1.7^{\mathrm{a}}$ & $18.4 \pm 1.5^{\mathrm{a}}$ & $16.6 \pm 0.2^{\mathrm{a}}$ & $0.031 \pm 0.007^{\mathrm{b}}$ \\
\hline $\mathrm{PB}$ & $15.9 \pm 1.7^{\mathrm{b}}$ & $32.8 \pm 1.8^{\mathrm{b}}$ & $46.8 \pm 1.0^{\mathrm{d}}$ & $0.151 \pm 0.003^{\mathrm{b}}$ \\
\hline $\mathrm{GB}$ & $25.5 \pm 0.6^{\mathrm{d}}$ & $39.0 \pm 0.9^{\mathrm{c}}$ & $26.8 \pm 1.4^{\mathrm{b}}$ & $0.143 \pm 0.009^{\mathrm{e}}$ \\
\hline $\mathrm{TE}$ & $68.3 \pm 0.4^{\mathrm{f}}$ & $62.1 \pm 0.5^{\mathrm{d}}$ & $20.6 \pm 0.8^{\mathrm{ab}}$ & $0.337 \pm 0.01{ }^{\mathrm{c}}$ \\
\hline $\mathrm{AM}$ & $18.5 \pm 1.4^{\mathrm{c}}$ & $40.1 \pm 2.3^{\mathrm{c}}$ & $40.4 \pm 6.3^{\mathrm{c}}$ & $0.230 \pm 0.001^{\mathrm{c}}$ \\
\hline
\end{tabular}

The concentrations used for DPPH, ABTS, and reducing power assays were $500 \mu \mathrm{g} / \mathrm{mL}$; for the nitrite scavenging activity assay $200 \mu \mathrm{g} / \mathrm{mL}$ were used. Different superscripts within a column indicate statistically significant differences $(p<0.05)$.

The potent nitrite scavenging activities of the PB and AM extracts are interesting (Table 6). Nitrite, as an important food additive in the meat processing industry, reacts with secondary amines to form nitrosoamine, which has emerged as a putative candidate responsible for colorectal cancer [56]. The consumption of excess amounts of nitrite could oxidize haemoglobin. The negative effects of nitrite on human health, including possible allergenic and vasodilator effects, were also reported [57]. Therefore, a reduction in nitrite exposure in protein-rich foods is helpful to reduce the development of colorectal cancer [56], and the idea of replacing nitrite with phytochemicals extracted from oregano or thyme provides an idea for the production of innovative processed meat [58]. However, there are no reports for the production of processed meat with $\mathrm{PB}$ and AM extracts to date Our results suggest 
the possible use of $\mathrm{PB}$ and $\mathrm{AM}$ extracts as anti-nitrite food ingredients in processed meat products, such as hams, sausages, bacons or crushed meats (Table 6). Furthermore, the extracts of PB did not show significant haeamolytic activity against RBC up to $1 \mathrm{mg} / \mathrm{mL}$. Therefore, the evaluation of nitrite reduction and increased antioxidant of the $\mathrm{PB}$ extract-containing processed meat is worth further study.

The antioxidant activities of the insect extracts are not related to the total polyphenol content (Tables 2 and 6). The correlation coefficients of total polyphenol to DPPH scavenging, ABTS scavenging, nitrite scavenging, and reducing power were $0.003,0.009,0.125$, and 0.094 , respectively. The correlation coefficients of total polyphenol in respect to anti-coagulation activities ( 0.121 for TT, 0.387 for PT, and 0.085 for aPTT), and platelet aggregation rate (0.002) were not significant. These results suggest that phenolic compounds are not connected with anti-oxidant, anti-coagulation and platelet aggregation. It could be argued that edible insects like those examined in this paper could serve as a potential source of anti-oxidant ingredients. However, since the anti-oxidant activity was not related to the total polyphenol content, this suggests that edible insects are endowed with redox ingredients, ranging from phenolics and proteins to unidentified compounds, able to counteract oxidative stress from water and a lipophilic environment [59]. The purification of active compounds is in progress, and non-phenolic, lipophilic molecules may be related to the anti-thrombosis and anti-oxidant effects.

\section{Conclusions}

Analyses of anti-coagulation, platelet aggregation, anti-oxidant and haemolytic activities of the six edible insects (Allomyrina dichotoma, Tenebrio molitor, Protaetia brevitarsis, Gryllus bimaculatus, Teleogryllus emma and Apis mellifera) have revealed that these insects have their own biological functionalities. Useful bioactivities of the six edible insects, such as the TE extract as an anti-coagulation, AD and TE extracts as anti-oxidation, $\mathrm{PB}$ and $\mathrm{AM}$ extracts as nitrite scavenging and TE and AM as hemolysis, were considered. The contents of polyphenol and flavonoids were not related to the antioxidant activity, which is dissimilar to the plant antioxidant system. All insect extracts except AM promoted platelet aggregation.

Author Contributions: Conceptualization, H.-Y.S.; methodology, S.-J.P., D.-G.K.; software, H.-Y.S., and S.-J.P.; validation, H.-Y.S. and S.-J.P.; formal analysis, S.-J.P. and D.-G.K.; investigation S.-J.P.; resources, C.J.; data curation, H.-Y.S. and C.J.; writing—original draft preparation, H.-Y.S.; writing-review and editing, C.J.; visualization, H.-Y.S.; supervision, H.-Y.S.; project administration, C.J.; funding acquisition, C.J. All authors have read and agreed to the published version of the manuscript.

Funding: This work was funded by the Ministry of Education, Science, and Technology (NRF-2018R1A6A1A03024862).

Acknowledgments: This work was supported by the Basic Research Program through the National Research Foundation of Korea (NRF) funded by the Ministry of Education, Science, and Technology (NRF-2018R1A6A1A03024862).

Conflicts of Interest: The authors declare no conflict of interest.

\section{References}

1. FAO. The State of Food Insecurity in the World. Available online: http://www.fao.org/hunger/keymessages/en/ (accessed on 15 January 2020).

2. Dossey, A.T.; Morales-Ramos, J.A.; Rojas, M.G. Insects as Sustainable Food Ingredients: Production, Processing and Food Applications; Elsevier: Amsterdam, The Netherlands, 2016.

3. Van Huis, A.; Van Itterbeeck, J.; Klunder, H.; Mertens, E.; Halloran, A.; Muir, G.; Vantomme, P. Edible Insects: Future Prospects for Food and Feed Security; Food and Agriculture Organization of the United Nations: Rome, Italy, 2013.

4. Cortes Ortiz, J.; Ruiz, A.T.; Morales-Ramos, J.; Thomas, M.; Rojas, M.; Tomberlin, J.; Yi, L.; Han, R.; Giroud, L.; Jullien, R. Insect mass production technologies. In Insects as Sustainable Food Ingredients; Elsevier: Amsterdam, The Netherlands, 2016.

5. Van Huis, A. Potential of insects as food and feed in assuring food security. Annu. Rev. Entomol. 2013, 58, 563-583. [CrossRef] [PubMed] 
6. Rumpold, B.A.; Schlüter, O.K. Nutritional composition and safety aspects of edible insects. Mol. Nutr. Food Res. 2013, 57, 802-823. [CrossRef] [PubMed]

7. Meyer-Rochow, V.B. Can insects help to ease then problem of world food shortage? Search 1975, 6, 261-262.

8. Pemberton, R.W. Insects and other arthropods used as drugs in Korean traditional medicine. J. Ethnopharmacol. 1999, 65, 207-216. [CrossRef]

9. Meyer-Rochow, V.B. Ethno-entomological observations from North Korea (officially known as the "Democratic People's Republic of Korea"). J. Ethnobiol. Ethnomed. 2013, 9, 7. [CrossRef] [PubMed]

10. Jung, C. Potential of insects as future food resources. Glob. Affairs Glob. Food Resour. Survival Strategy Korea 2016, 16, 77-89.

11. Kim, H.S.; Jung, C. Nutritional characteristics of edible insects as potential food materials. Korean J. Apic. 2013, 28, 1-8.

12. Sah, L.P.; Jung, C. Global perspective of edible insects as human food. Korean J. Soil Zool. 2012, 16, 1-8.

13. Ghosh, S.; Jung, C.; Meyer-Rochow, V.B. Nutritional value and chemical composition of larvae, pupae, and adults of worker honey bee, Apis mellifera ligustica as a sustainable food source. J. Asia Pac. Entomol. 2016, 19, 487-495. [CrossRef]

14. Ghosh, S.; Lee, S.M.; Jung, C.; Meyer-Rochow, V.B. Nutritional composition of five edible insects of South Korea. J. Asia Pac. Entomol. 2016, 20, 686-694. [CrossRef]

15. Seo, M.; Goo, T.-W.; Chung, M.; Baek, M.; Hwang, J.-S.; Kim, M.; Yun, E.-Y. Tenebrio molitor larvae inhibit adipogenesis through AMPK and MAPKs signaling in 3T3-L1 adipocytes and obesity in high-fat diet induced obese mice. Int. J. Mol. Sci. 2017, 18, 518. [CrossRef] [PubMed]

16. Lee, J.E.; Lee, A.J.; Jo, D.E.; Cho, J.H.; Youn, K.J.; Yun, E.Y.; Hwang, J.S.; Jun, M.R.; Kang, B.H. Cytotoxic effects of Tenebrio molitor larval extracts against hepatocellular carcinoma. Korean Soc. Food Sci. Nutr. 2015, 44, 200-207. [CrossRef]

17. Gessner, D.K.; Schwarz, A.; Meyer, S.; Wen, G.; Most, E.; Zorn, H.; Ringseis, R.; Eder, K. Insect meal as alternative protein source exerts pronounced lipid-lowering effects in hyperlipidemic obese Zucker rats. J. Nutr. 2019, 149, 566-577. [CrossRef] [PubMed]

18. Lee, J.H.; Kim, I.W.; Kim, M.A.; Yun, E.Y.; Hwang, J.S. Pharmaco-medical application of antimicrobial peptides derived from insect. J. Life Sci. 2016, 26, 737-748. [CrossRef]

19. Frangieh, J.; Salma, Y.; Haddad, K.; Matteri, C.; Legros, C.; Fajloun, Z.; El obeid, D. First characterization of the venom from Apis mellifera syriaca, a honeybee from the middle east region. Toxins 2019, 11, 191. [CrossRef] [PubMed]

20. Gong, J.; Yuan, H.; Gao, Z.; Hu, F. Wasp venom and acute kidney injury: The mechanisms and therapeutic role of renal replacement therapy. Toxicons 2019, 163, 1-7. [CrossRef]

21. Xi, X.; Guo, S.; Guo, H.; Cui, X.; Cao, H.; Xu, F.; Zheng, M.; Li, Y.; Han, C. Anti-exercise-fatigue and promotion of sexual interest activity of total flavonoids from wasps drone-pupae in male mice. Biomed. Pharmacother. 2018, 107, 254-261. [CrossRef]

22. Kim, M.S.; Shin, W.C.; Kang, D.K.; Sohn, H.Y. Anti-thrombosis activity of sinapic acid isolated from the lees of bokbunja wine. J. Microbiol. Boptechnol. 2016, 26, 61-65. [CrossRef]

23. Szczeklik, A.; Musial, J.; Undas, A.; Swadzba, J.; Gora, P.F.; Piwowarska, W.; Duplaqa, M. Inhibition of thrombin generation by aspirin is blunted in hypercholesterolemia. Arterioscler. Thromb. Vasc. Biol. 1996, 16, 948-954. [CrossRef]

24. Sweeney, J.D.; Hoerning, L.A.; Behrens, A.N.; Novak, E.; Swank, R.T. Thrombocytopenia after desmopressin but absence of in-vitro hypersensitivity to ristocetin. Am. J. Clin. Path. 1990, 93, 522-525. [CrossRef]

25. Wang, J.; Xiong, X.; Feng, B. Aspirin resistance and promoting blood circulation and removing blood stasis: Current situation and prospectives. Evid. Complement. Alter. Med. 2014,1-11. [CrossRef] [PubMed]

26. Lee, H.; Woo, E.; Lee, D.G. Nortrachelogenin from Partrinia scabiosaefolia elicits an apoptotoc response in Candida albicans. FEMS Yeast Res. 2016, 16, fow013. [CrossRef] [PubMed]

27. Suzuki, Y.J.; Forman, H.J.; Sevanian, A. Oxidants as stimulators of signal transduction. Free Radic. Biol. Med. 1997, 22, 269-285. [CrossRef]

28. Taipong, K.; Boonprakob, U.; Crosby, K.; Cisneros-Zevallos, L.; Byrne, D.H. Comparison of ABTS, DPPH, FRAP, and ORAC assays for estimating antioxidant activity from guava fruit extracts. J. Food Comp. Anal. 2006, 19, 669-675. [CrossRef] 
29. Kim, D.B.; Shin, G.H.; Lee, Y.J.; Lee, J.S.; Cho, J.H.; Baik, S.O.; Lee, O.H. Assessment and comparison of the antioxidant activities and nitrite scavenging activity of commonly consumed beverages in Korea. Food Chem. 2014, 151, 58-64. [CrossRef] [PubMed]

30. Jayaprakasha, G.K.; Singh, R.P.; Sakariah, K.K. Antioxidant activity of grape seed (Vitis vinifera) extracts on peroxidation models in vitro. Food Chem. 2001, 73, 285-290. [CrossRef]

31. Singleton, V.L.; Orthofer, R.; Lamuela-Raventos, R.M. Analysis of total phenols and other oxidation substrates and antioxidants by means of folin-ciocalteu reagent. Methods Enzymol. 1999, 299, 152-178.

32. Jing, L.; Ma, H.; Fan, P.; Gao, R.; Jia, Z. Antioxidant potential, total phenolic and total flavonoid contents of Rhododendron anthopogonoides and its protective effect on hypoxia-induced injury in PC12 cells. BMC Complement Altern. Med. 2015, 15, 287. [CrossRef]

33. Masuko, T.; Minami, A.; Iwasaki, N.; Majima, T.; Nishimura, S.; Lee, Y.C. Carbohydrate analysis by a phenol-sulfuric acid method in microplate format. Anal. Biochem. 2005, 339, 69-82. [CrossRef]

34. Silveira, M.H.; Aquiar, R.S.; Siika-aho, M.; Ramos, L.P. Assessment of the enzymatic hydrolysis profile of cellulose substrates based on reducing sugar release. Bioresur. Technolol. 2014, 151, 392-396. [CrossRef]

35. Wang, L.; Li, L.; Wang, H.; Liu, J. Study on the influence of oxidative stress on the fibrillization of fibrinogen. Sci. Rep. 2017, 7, 12429. [CrossRef]

36. Martinez, M.; Weisel, J.W.; Ischiropoulos, H. Functional impact of oxidative posttranslational modifications on fibrinogen and fibrin clots. Free Radic. Biol. Med. 2013, 65, 411-418. [CrossRef]

37. Bijak, M.; Nowak, P.; Borowiecka, M.; Ponczek, M.B.; Zbikowska, H.M.; Wachowicz, B. Protective effects of (-)-epicatechin against nitrative modifications of fibrinogen. Thromb. Res. 2012, 130, e123-e128. [CrossRef]

38. Meyer-Rochow, V.B. Therapeutic arthropods and other, largely terrestrial, folk-medicinally important invertebrates: A comparative survey and review. J. Ethnobiol. Ethnomed. 2017, 13, 9. [CrossRef] [PubMed]

39. Lee, J.H.; Baek, M.H.; Lee, H.J.; Kim, I.W.; Kim, S.Y.; Seo, M.C.; Kim, M.A.; Kim, S.H.; Hwang, J.S. Anti-inflammatory activity of antimicrobial peptide protaetiamycine 2 derived from the Protaetia brevitarsis seulensis. J. Life Sci. 2019, 29, 1218-1226.

40. Shi, Y.N.; Tu, Z.C.; Wang, X.L.; Yan, Y.M.; Fang, P.; Zuo, Z.L.; Hou, B.; Yang, T.H.; Cheng, Y.X. Bioactive compounds from the insect Aspongopus chinensis. Bioorg. Med. Chem. Lett. 2014, 24, 5164-5169. [CrossRef] [PubMed]

41. Cho, H.R.; Lee, Y.J.; Hong, J.E.; Lee, S.O. Enzymatic preparation and antioxidant activities of protein hydrolysates from Gryllus bimaculatus. Korean J. Food Sci. Technol. 2019, 51, 473-479.

42. Hahn, B.S.; Jo, Y.Y.; Yang, K.Y.; Wu, S.J.; Pyo, M.K.; YunChoi, H.S.; Kim, Y.S. Evaluation of the in vivo antithrombotic, anticoagulant and fibrinolytic activities of Lumbricus rubellus earthworm powder. Arch. Pharm. Res. 1997, 20, 17-23. [CrossRef]

43. Xu, X.; Liu, W.; Li, W.; Liu, S. Anticoagulant activity of crude extract of Holotrichia diomphalia larvae. J. Ethnopharmacol. 2016, 177, 28-34. [CrossRef]

44. Lee, J.; Lee, W.; Kim, M.A.; Hwang, J.S.; Na, M.; Bae, J.S. Inhibition of platelet aggregation and thrombosis by indole alkaloids isolated from the edible insect Protaetia brevitarsis seulensis (Kolbe). J. Cell Mol. Med. 2017, 21, 1217-1227. [CrossRef]

45. Lee, W.; Lee, J.; Kulkarni, R.; Kim, M.A.; Hwang, J.S.; Na, M.; Bae, J.S. Antithrombotic and antiplatelet activities of small-molecule alkaloids from Scolopendra subspinipes mutilans. Sci. Rep. 2016, 6, 21956. [CrossRef]

46. Chagas, A.C.; McPhie, P.; San, H.; Narum, D.; Reiter, K.; Tokomasu, F.; Brayner, F.A.; Alves, L.C.; Ribeiro, J.M.; Calvo, E. Simplagrin, a platelet aggregation inhibitor from Simulium nigrimanum salivary glands specifically binds to the Von Willebrand factor receptor in collagen and inhibits carotid thrombus formation in vivo. PLoS Negl. Trop. Dis. 2014, 8, e2947. [CrossRef] [PubMed]

47. Choi, J.H.; Kim, S.J.; Kim, S. A novel anticoagulant protein with antithrombotic properties from the mosquito Culex pipiens pallens. Int. J. Biol. Macromol. 2016, 93, 156-166. [CrossRef] [PubMed]

48. Zhang, Z.; Gao, L.; Shen, C.; Rong, M.; Yan, X.; Lai, R. A potent anti-thrombosis peptide (vasotab TY) from horsefly salivary glands. Int. J. Biochem. Cell Biol. 2014, 54, 83-88. [CrossRef] [PubMed]

49. Kong, Y.; Xu, C.; He, Z.L.; Zhou, Q.M.; Wang, J.B.; Li, Z.Y.; Ming, X. A novel peptide inhibitor of platelet aggregation from stiff silkworm, Bombyx batryticatus. Peptides 2014, 53, 70-78. [CrossRef] [PubMed] 
50. Blankespoor, C.L.; Pappas, P.W.; Eisner, T. Impairment of the chemical defense of the beetle, Tenebrio molitor, by metacestodes (cysticeroides) of the tapeworm, Hymenolepsis diminuta. Parasitology 1997, 115, 105-110. [CrossRef] [PubMed]

51. Shander, A.; Javidroozi, M.; Ashton, M.E. Drug-induced anemia and other red cell disorders: A guide in the age of polypharmacy. Curr. Clin. Pharmacol. 2011, 6, 295-303. [CrossRef]

52. Matarrese, P.; Straface, E.; Pietraforte, D.; Gambardella, L.; Vona, R.; Maccaglia, A.; Minetti, M.; Malorni, W. Peroxynitrite induces senescence and apoptosis of red blood cells through the activation of aspartyl and cysteinyl proteases. FASEB J. 2005, 19, 416-418. [CrossRef]

53. Petz, L.D.; Fudenberg, H.H. Coombs-positive hemolytic anemia caused by penicillin administration. N. Engl. J. Med. 1966, 274, 171-178. [CrossRef]

54. Ehmann, W.C. Cephalosporin-induced hemolysis: A case report and review of the literature. Am. J. Hematol. 1992, 40, 121-125. [CrossRef]

55. Franck, P.; Bevers, E.M.; Lubin, B.H.; Comfurius, P.; Chiu, D.T.; Op den Kamp, J.A.; Zwaal, R.F.; van Deenen, L.L.; Roelofsen, B. Uncoupling of the membrane skeleton from the lipid bilayer. The cause of accelerated phospholipid flip-flop leading to an enhanced procoagulant activity of sickled cells. J. Clin. Investig. 1985, 75, 183-190. [CrossRef] [PubMed]

56. Crowe, W.; Elliott, C.T.; Green, B.D. A review of the In Vivo evidence investigating the role of nitrite exposure from processed meat consumption in the development of colorectal cancer. Nutrients 2019, 11, 2673. [CrossRef] [PubMed]

57. Rivera, N.; Bunning, M.; Martin, J. Uncured-labeled meat products produced using plant-derived nitrates and nitrites: Chemistry, safety, and regulatory considerations. J. Agric. Food Chem. 2019, 67, 8074-8084. [CrossRef] [PubMed]

58. Hung, Y.; Verbeke, W.; de Kok, T.M. Stakeholder and consumer reactions towards innovative processed meat products: Insights from a qualitative study about nitrite reduction and phytochemical addition. Food Control 2016, 60, 690-698. [CrossRef]

59. Mattia, C.D.; Battista, N.; Sacchetti, G.; Serafini, M. Antioxidant activities in vitro of water and liposoluble extracts obtained by different species of edible insects and Invertebrates. Front. Nutr. 2019, 6, 106. [CrossRef] [PubMed]

(C) 2020 by the authors. Licensee MDPI, Basel, Switzerland. This article is an open access article distributed under the terms and conditions of the Creative Commons Attribution (CC BY) license (http://creativecommons.org/licenses/by/4.0/). 